\title{
Why the Conflicts between the Hans and the Hsiung-nu Happened?
}

\author{
Houjun Gong \\ United World College in Changshu of China, Changshu, China \\ Email: cis2018@foxmail.com
}

How to cite this paper: Gong, H. J. (2020). Why the Conflicts between the Hans and the Hsiung-nu Happened? Advances in Historical Studies, 9, 38-44.

https://doi.org/10.4236/ahs.2020.92004

Received: April 22, 2020

Accepted: June 16, 2020

Published: June 19, 2020

Copyright $\odot 2020$ by author(s) and Scientific Research Publishing Inc. This work is licensed under the Creative Commons Attribution-NonCommercial International License (CC BY-NC 4.0). http://creativecommons.org/licenses/by-nc/4.0/ (c) (i) \& Open Access

\begin{abstract}
This essay discusses the origin, purpose and undeniable external circumstances that influenced Hsiung-nu's long-lasting, perseverant military invasion movement of the Chinese Central-Plain-region regimes. Contents in this essay are cited from the article written by Daniel C. Waugh (2010), "Selection from the Han Narrative Histories". This article includes tremendous amount of information about the origin and development of Hsiung-nu's culture, its living environment of Hsiung-nu and the conflict between it and Han Dynasty. Referenced content is used to deduce possible motivations for the Hsiung-nu military movement to not only the Han Dynasty, but also each generation of the Chinese regimes set in the Central Plain region. Hsiung-nu people lived in an environment with a much lower temperature than that of the Central Plain region; the area Hsiung-nu lived also has little arable land which leads to poor agriculture and insuffcient food production. Comparing with the poor and harsh environment in their living area, the Central Plain was obviously a considerable lure to Hsiung-nu. The problem came with the vast territory of regimes in the region, so Hsiung-nu came up with the idea to assault the border, rob labor force and herd, then force Central-Plain government to pay more resources from them to stop the conflict. Thus, a relatively stable income was created by this fierce and wise race to sustain their livelihoods.
\end{abstract}

\section{Keywords}

Hsiung-nu, Central Plain China, Military Invasion, Natural and Economic Condition

\section{Introduction}

Many of the historical documents of the Hsiung-nu people we can find is mostly 
written by ancient Chinese historians. Such as "Hanshu", the historical documentation records the history of Han Dynasty and also recorded a lot fact about Hsiung-nu about the wars and invasions. Hsiung-nu was described as a group of uncivilized people who raided around the border of China and is one of the oldest and longest-lasting enemies of the government in the Central Plain of China. They were famous for their small population and great military force; they used their advantage in horse-riding to form an army cavalry in thousands of men, which acted as a formidable enemy of the main military force, the infantry of China. They are often described in history as a greedy, violent and aggressive race that lived in the north of the Central Plain region. They used their cavalry to raid around the border of China and grabbed animals and people from China ${ }^{1}$.

In my opinion, Hsiung-nu was not just a group of savage nomads that rode on horses and raided everywhere, but a group of smart and strong people who clearly knew what they wanted and needed. Their herds could not support their growing desire for a better life and the amount of necessary nutrition for an increasing population. These harsh conditions forced them to grab commodities and crops from the fertile and prosperous central plain's land to supply enough goods and consumables to their women and children to survive in the steppe. They also knew that continuing to raid along the border would bring war to the whole race, so they decided to sign treaties with the Han government and got ahuge quantity of food and precious goods from it in order to avoid military conflict. In this paper, I seek to state and support my claims about why the military conflict between Hsiung-nu and Han started and continued on economics conception.

\section{Hsiung-nu's Living and Economic Conditions}

When doing research on a civilization, some of the most important things to understand are its living and economic conditions. Based on these two factors, when doing research on a certain topic, we can learn more about the background information about a culture. Thus, we can discover much more information by analyzing the living and economic condition of that culture to better explain and provide a context for its actions and historical events. Also, such information can help us better understand why a policy was published or why a choice was made when these decisions seem ridiculous or even illogical nowadays.

How Hsiung-nu's life went on during the period of the Han dynasty is quite an important topic of research. What influences a culture the most is its living and economic conditions, which often dictates its life and motivates behaviors. These factors decided what policies the culture adopted to develop itself as well as how that group interacted with other cultures. Undoubtedly, they lived a life really similar as a group of uncivilized savages in the view of people who lived in

${ }^{1}$ Detailed information about what the Hsiung-nu raided from border of China and also about what and why they raided can be found in Daniel C. Waugh's (2010) Selection from the Han Narrative Histories. 
the central plain region in the Han dynasty of China. From the "Selection from the Han Narrative Histories", Hsiung-nu nomads lived mainly on their herdsthe animals they fed. "These were the Heen-yun or Heun-yuh, who inhabited the northern regions, and removed from place to place, according to the pasturage for their flocks and herds." ${ }^{2}$ This passage showcases that Hsiung-nu nomads' living area was mainly dependent on the pasture region that could feed their herds. Also, the essay mentioned that "Removing their herds to find water and pasturage, they had no cities. But dwelt on their rural patrimonies, each family having its allotted portion of land." 3 The word "no cities" directly tells us that Hsiung-nu did not live in a fixed area like people who lived in the central plain area did but lived in the "rural patrimony" which I believe is the tent they lived in. The "allotted portion of land" obviously, is the allotted pasture they herded their animals. These sentences show us the basic living habit of Hsiung-nu. They lived in the tents left over by ancestors and moved around in the steppe to find new available pasture land and settled there. When the grass was finished by their herds, they repeated the previous procedure and settled in new pastures. They repeated this process to survive.

Why would the Hsiung-nu act this way? Evidently, the lack of cultivable lands in the steppe region. Hsiung-nu could not plant enough crops as people in the central plain region did. People who lived in the central plain had the Yellow River flowing through the land, bringing flood, including fertile land and plenty of nutrition to the soil. Also, the land was widely and evenly distributed in the central plain, which also made it more fitting to plant crops. Moreover, the central plain region had warm enough weather to make it possible for crops to be mature not only once a year to support the growing population. But things became different in the region where the Hsiung-nu lived-the climate was not warm and there were no rivers flowing through the northern region of the central plain as such conditions were even harder to support the crops to grow. Therefore, we can assume that life was harsh for the Hsiung-nu in the steppe; if they only lived on the commodities that were produced by their herds, they couldn't expand or even survive there.

Such harsh economic conditions shaped the Hsiung-nu to become a totally different culture as compared to the Han. Hsiung-nu became a race that advocated for power and military force with small numbers of populations as compared with those in the central plain of China. Hsiung-nu people were required to learn how to ride and use bows when they were still children-they rode on sheep back and used their small bows to shoot birds and squirrels ${ }^{4}$. As we know, both of these two kinds of prey are small and they move really fast; it is hard even for an adult to shoot them, but Hsiung-nu people hunted them to conduct daily military training when they were still children. When the children grew ${ }^{2}$ Daniel C. Waugh (2010), Selection from the Han Narrative Histories, page 2, I. The "Heen-yuh" (also appeared in the Selection from the Han Narrative Histories as "Heun-yuh") was a group of the Hsiung-nu nomads lived in the northern region as the essay described.

${ }^{3}$ Daniel C. Waugh (2010), Selection from the Han Narrative Histories, page 2, I.

${ }^{4}$ Daniel C. Waugh (2010), Selection from the Han Narrative Histories, page 2, I. 
older, they "shot foxes and hares, the flesh of which they ate", which means they started to hunt for themselves and their own families. Foxes and hares are animals a bit larger than birds and squirrel, but they are stronger, faster and quicker than birds and squirrels. This means that it became harder for children to finish their training and it is more dangerous because foxes are a kind of carnivore and predator. They also posed a threat to these children, but all the weapons these children had were their bows and useless sheep. Through such training, Hsiungnu children not only knew how to use bows well and shoot moving targets, but they also learned how to ride and develop their courage. But, of all this training, the most important skill that Hsiung-nu children learnt was horseback archery. It was precisely this skill that cavalries in the central plain region always tried to learn but could not master. This was the strongest weapon and pure advantage that nomads had in conquering the central plain army.

Hsiung-nu was also particularly careful about the efficiency of their human resource use and production. Based on Hsiung-nu's rule, "When a father died, they would marry his widowed mother; and when a brother died, it was customary to marry his widow. Their names were not transmitted to their descendants. ${ }^{\prime 6}$ From this rule we can find that Hsiung-nu's policy actually encouraged people to have more births. This policy about marrying widows seems like an uncivilized race's choice, but this custom actually treats women as instruments of bearing babies and keeping the population of the race in a relatively stable number from the endless warfare they needed to faced. The process of eliminating the dead people's name from his widows' children, from my point of view, was trying to strengthen the bond of the members in a group. Children needed to learn the skill of fighting, and they would prefer the closest person to teach them It was human nature for then to prefer those that were close to teach them new things rather than strangers. In the ancient world, sharing one name meant that they were all from one big family, and if this person was also his/her parents, the closest relationship they might have in society, then the child would definitely be willing to learn from them.

The group's avocation for military force and power was represented in their daily religion and contribution reward. Hsiung-nu was a race that developed on raiding and wars but had small population, so strong and brave warriors were what they needed the most. Hsiung-nu always rewarded their warriors after military activities. From the King to normal members of the race, everyone could eat meat from domestic animals and wear clothes made from animals' skin. Strong people ate the fat part they picked, but old and weak people could only eat meat that had been left. Strong people were respected and weak people got contempt ${ }^{7}$. This action was aimed at encouraging people to become strong so that they could get better meat during the reward ceremony. For a civilization that turned all men into soldiers like Hsiung-nu, stronger men meant reliable

\footnotetext{
${ }^{5}$ Daniel C. Waugh (2010), Selection from the Han Narrative Histories, page 2, I.

${ }^{6}$ Daniel C. Waugh (2010), Selection from the Han Narrative Histories, page 3, I.

${ }^{7}$ Daniel C. Waugh (2010), Selection from the Han Narrative Histories, page 2, I.
} 
soldiers in battle, which meant a stronger military force. The rule that only rewards people after victory also inspired soldiers to fight braver and fiercer in the battle in order to incentivize Hsiung-nu people to win wars and maintain their survival.

\section{Conflicts, Treaties and Commodities}

The first officially recorded military contact between the Hsiung-nu and Han happened during the year Shen-yu Maou-tun ruled Hsiung-nu when it was in middle of third century BC. Hsiung-nu and Han, respectively led by Shen-yu Maou-tun, who was one of the most famous Shen-yu in Hsiung-nu history, and Emperor of Han, Kaou-te. The war was started by the rebellion of one prince called Sin. He set his capital at Ma-ye $\mathrm{e}^{8}$ and made an alliance with Hsiung-nu. Kaou-te defended the invader in winter, but the soldiers from the Central Plain could not bear the cold and $20 \%-30 \%$ of them lost their fingers under the extremely cold weather. Maou-tun showed Kaou-te the vision that Hsiung-nu's army was weak, Kaou-te tried to finish the battle quickly, so he led his army run after Hsiung-nu. But when Maou-tun appeared with his picked soldiers, Han army was defeated and surrounded for seven days. Finally, Kaou-te made contact with the consort of Shen-yu. By bribing her with liberty and influence, Kaou-te successfully let the consort to persuade Shen-yu with words recorded as "Why should two sovereigns distress each other? Having now gotten possession of the Han territory, the Shen-yu can never occupy it; moreover, the Shen-yu sacrifices to the spirits of the Lord of Han." At last, Shen-yu let Kaou-te leave and made a treaty about the relationship between Han and Hsiung-nu'.

As an exchange for peace and harmony, the Han emperor sent a princess to Hsiung-nu as a consort of Shen-yu, and based on the treaty Han and Hsiung-nu made and the policy which Han used to treat the relationship with Hsiung-nu, also sent raw and woven silk, wine and food to Hsiung-nu to promote the friendly relationship ${ }^{10}$. Shen-yu sent a letter to the Han emperor in the next year of the war; the letter was so-called as that which asked for long lasting peace but was actually a threatening one by showing Hsiung-nu's power to ask for more food, silk and silver from Han. It mentioned that Hsiung-nu had conquered 26 kingdoms in the north region and combined all the military power together under the control of Hsiung-nu. It is mentioned in Daniel C. Waugh's book (Selection from the Han Narrative Histories ${ }^{11}$ ) that:

"our officers and troops were loyal and true, our horses were strong and spirited; and buy slaughter, decapitation, subjugation and pacification, our army effected the complete reduction of the Yue-te, while Lou-lan, Wu-sun, Hoo-kee and the adjacent kingdoms, to the number of twenty-six in all, without exception, submitted to the Hsiung-nu; and thus all the bowmen nations are united as

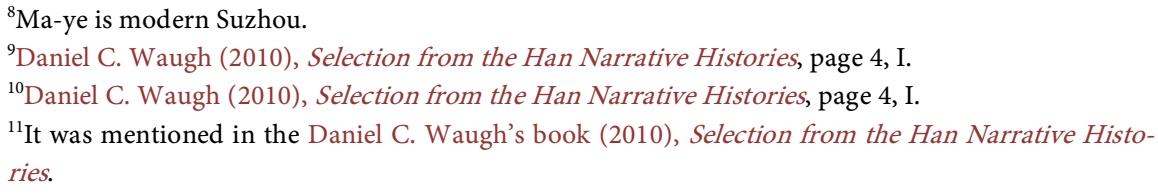


one family. Having also tranquillized the northern lands, we are now desirous that there should be a cessation of hostilities, and that the troops should send their horses to pasture." There were still several sentences followed that asked for the land, but we can easily find the hidden information in the letter from Shen-yu, he was directly requiring Han remove the army settled in the border and cleaned the plain with Chinese farmers and land without the protection of soldiers who were that was the perfect condition for Hsiung-nu to raid."

The Han emperor was angry with this letter and sent messengers to Hsiungnu to clear the real aim of this nomad tribe. He made an assembly to ask his ministers about how to treat Hsiung-nu. The ministers were broken into two sidesone side suggested that they should fight with Hsiung-nu and conquer them as revenge for the threatening letter, but the other side said it is impolitic to make an attack on Hsiung-nu since they had just gotten the prestige of victory. Also, the land and water in Hsiung-nu's territory were not available for agriculture ${ }^{12}$, thus it was unnecessary to conquer them. The emperor took the peace's advice and sent 82 pieces of precious clothes and some ornament to Hsiung-nu with a warning letter. But just several years later, in the year $166 \mathrm{BCE}$, Hsiung-nu raided the border, killed local government officers and burnt palaces, but when the Han army arrived, Hsiung-nu retreated and hid. Han could not catch up the speed of Hsiung-nu's horses and were forced to send gold, silk and crops to Hsiung-nu every year. Even after Maou-tun Shen-yu died, his son, Keun-shin Shen-yu also organized several invasions during his reign also killed Han border officers as his father did and made Han send other princess to Hsiung-nu and build new forts to defend Hsiung-nu ${ }^{13}$ Invasion, treaty and invasion, this circle was the perfect portraiture of the relation between Hsiung-nu and Han in the early period.

When $\mathrm{Wu}$-ti inherited the huge empire and upreme power from his father, the Han had already become a powerful empire. In the year $135 \mathrm{BCE}$, Wu-ti sent an army of over three hundred thousand people to attack Hsiung-nu. Although this battle was a fight without any contribution, the number of the army had already proved the power of $\mathrm{Han}^{14}$. Wu-ti also sent Chang K'ien, who was called Zhang Qian in Chinese, one of the most famous envoys in the whole Chinese history, to visit Central Asian kingdoms to find available allies, but Chang K'ien was caught by Hsiung-nu and imprisoned him for ten years. Chang K'ien visited several Kingdoms such as Yue-chi and learned a lot about surrounding nomads and kingdoms ${ }^{15}$. This made the basics of the following victory of Han against Hsiung-nu.

In the year $87 \mathrm{BCE}, \mathrm{Wu}$-ti died and Chaou te inherited from him. Since that year, Han started to pursue and attack Hsiung-nu, which lasted for 20 years. At

${ }^{12}$ In the Selection from the Han Narrative Histories written by Daniel C. Waugh, it was mentioned that the water in Hsiung-nu's living region was with salt that was impossible to be used in agriculture.

${ }^{13}$ Daniel C. Waugh (2010), Selection from the Han Narrative Histories, page 7-8, I.

${ }^{14}$ Daniel C. Waugh (2010), Selection from the Han Narrative Histories, page 9, II.

${ }^{15}$ Daniel C. Waugh (2010), Selection from the Han Narrative Histories, page 9-23, III. 
the same time, the reigning Shen-yu organized another raiding to the border, but was stopped by the forts and smoke towers, although they still grabbed several officers. Since then, the invasions of Hsiung-nu against Han became less and less advantageous, and with internal split of Hsiung-nu, they started to send hostages and tributes to Han and kneel to the former enemy ${ }^{16}$.

\section{Conclusion}

From the previous evidence and analysis, it can be concluded that the characteristics of Hsiung-nu's living and economic conditions were harsh. They lived in the northern steppe with no cultivable and which was caused by the cold weather and salt water. They had to shift from place to place to feed their herds to support the basic food they got for living in the steppe. This is, at least, Hsiung-nu's condition in Han Dynasty. What Hsiung-nu did during Han Dynasty was mostly raiding the border of central plain, grabbing its officers, farmers and crops from central plain and forcing the Chinese government to sign treaties with them, full of content about peace and tribute from Han to Hsiung-nu to "buy" the peace. Hsuing-nu's aim was always clear as I believe: they were just going straight for the crops and precious metals; all the battles they started and treaties signed were all about crops and precious metals. Crops could support more and healthier people, which meant a larger and stronger army in the tribe since they mainly lived on meat, and precious metal could promote trade and help Hsiung$\mathrm{nu}$ get contacts with other regions to find more suitable land for themselves. All of these were the desire about surviving in the steppe and growing bigger. Even in the later period they yielded to Han, they did so to survive. The reason why they had such a strong desire for survival was actually caused by their living and economic conditions. So, to conclude, the main cause of the military conflicts between Hsiung-nu and Han was the poor economic conditions that ingrained in the Hsiung-nu people a strong desire for survival that forced them to be aggressive, but not because of Hsiung-nu's greed or inclination for violence.

\section{Acknowledgements}

I would like to thank Professor Richard Payne who gave me advice about specifying my topic and the CIS team which gave me the chance to access the resources and finish the update of this essay.

\section{Conflicts of Interest}

The author declares no conflicts of interest regarding the publication of this paper.

\section{References}

Waugh, D. C. (2010). Selection from the Han Narrative Histories (pp. 4-24).

${ }^{16}$ Daniel C. Waugh (2010), Selection from the Han Narrative Histories, page 23-24, IV. 